\title{
Lab-scale periphyton-based system for fish culture
}

\author{
Sistema laboratorial baseado em perifíton para piscicultura
}

\section{Davi de Holanda Cavalcante ${ }^{I}$ Suzete Roberta da Silva ${ }^{\mathrm{I}}$ Paloma Damasceno Pinheiro ${ }^{\mathrm{I}}$ Ádila da Cunha Martins ${ }^{\mathrm{I}}$ Marcelo Vinícius do Carmo e Sá ${ }^{*}$}

\begin{abstract}
The present research aimed to assess a lab-scale model to study periphyton-based systems for fish culture. Twentyfive liters plastic aquaria were stocked with three Nile tilapia, Oreochromis niloticus, juveniles $\left(0.77 \pm 0.09 \mathrm{~g} ; 12\right.$ fish $\left.\mathrm{m}^{-2}\right)$ for 6 weeks in a $2 \times 2$ factorial design. Small plastic bottles were placed in some aquaria for periphyton development. Two feeding regimes were employed: "full-fed" (standard feeding rates were fully adopted) and "half-fed" (50\% of standard feeding rates). Growth performance and limnological variables were observed in each aquarium. There werefive replicates per treatment. Fish have fed actively on periphyton, especially in the half-fed aquaria. The placement of periphyton bottles had no significant effects on the water quality variables, except by the gross primary productivity which became lower. Half-fed aquaria presented lower concentrations of ammonia (0.28$\left.0.29 \mathrm{mg} \mathrm{L}^{-1}\right)$, nitrite $\left(0.33-0.37 \mathrm{mg} \mathrm{L}^{-1}\right)$ and phosphorus (0.42$\left.0.43 \mathrm{mg} \mathrm{L} \mathrm{L}^{-1}\right)$ than full-fed aquaria $\left(0.57-0.60 \mathrm{mg} \mathrm{L}^{-1} ; 0.75\right.$ $0.77 \mathrm{mg} \mathrm{L}^{-1} ; 0.67-0.70 \mathrm{mg} \mathrm{L}^{-1}$, respectively). The final body weight of fish in half-fed aquaria with periphyton bottles $(6.22 \pm 0.64 \mathrm{~g})$ was significantly higher than in aquaria without bottles $(4.65 \pm 0.36 \mathrm{~g})$. Although the growth rate of fish was lower in the half-fed aquaria (4.27-4.72 vs. 5.29-5.61\% BW day $\left.{ }^{-1}\right)$, survival was significantly higher when compared to the full-fed aquaria (93.3-100.0 vs. 80.0-83.4\%). Only in the aquaria with periphyton the feed conversation ratio was improved by the feeding restriction regime.
\end{abstract}

Key words: periphyton, tilapia, feeding restriction, fish culture.

\section{RESUMO}

O presente trabalho teve como objetivo avaliar um modelo laboratorial para estudo de sistemas de cultivo de peixes baseados em perifíton. Aquários de $25 \mathrm{~L}$ foram estocados com três juvenis de tilápia do Nilo, Oreochromis niloticus $\left(0,77 \pm 0,09 \mathrm{~g} ; 12\right.$ peixes $\left.\mathrm{m}^{-2}\right)$ por seis semanas, em arranjo fatorial 2x2. Pequenas garrafas plásticas foram colocadas em determinados aquários para o desenvolvimento de perifíton. Dois regimes alimentares foram empregados: "cheio", no qual taxas alimentares padrões foram integralmente adotadas $e$ "metade", em que 50\% das taxas alimentares regulares foram empregadas. Variáveis limnológicas e de desempenho zootécnico foram observadas em cada aquário. Havia cinco repetições por tratamento. Os peixes ingeriram ativamente perifiton, especialmente os que receberam metade do arraçoamento padrão. A colocação de garrafas para o crescimento de perifíton não teve efeito significativo nas variáveis de qualidade de água, excetuando-se na produtividade primária bruta que foi menor. Os aquários arraçoados pela metade apresentaram menores concentrações de amônia $\left(0,28-0,29 \mathrm{mg} \mathrm{L}^{-1}\right)$, nitrito $\left(0,33-0,37 \mathrm{mg} \mathrm{L}^{-1}\right)$ e fósforo $\left(0,42-0,43 \mathrm{mg} \mathrm{L}^{-1}\right)$ que os aquários arraçoados integralmente (0,57-0,60mg $\mathrm{L}^{-1} ; \quad$ 0,75-0,77mg $\mathrm{L}^{-1} ; 0,67-0,70 \mathrm{mg} \quad \mathrm{L}^{-1}$, respectivamente). O peso corporal final dos peixes nos aquários arraçoados pela metade, mas com garrafas para perifíton $(6,22 \pm 0,64 \mathrm{~g})$, foi significativamente maior que nos respectivos aquários sem garrafas $(4,65 \pm 0,36 \mathrm{~g})$. Embora a taxa de crescimento dos peixes alimentados com metade das taxas regulares tenha sido menor (4,27-4,72 vs. 5,29-5,61\% PC dia $\left.{ }^{-1}\right)$, a sobrevivência foi significativamente maior para estes, quando comparados com os peixes alimentados com taxas regulares (93,3-100,0 vs. 80,0-83,4\%). Apenas nos aquários com perifíton a conversão alimentar foi melhorada pela restrição alimentar imposta.

Palavras-chave: perifíton, tilápia, restrição alimentar, piscicultura.

'Laboratório de Ciência e Tecnologia Aquícola, Departamento de Engenharia de Pesca, Centro de Ciências Agrárias (CCA), Universidade Federal do Ceará (UFC), Campus Universitário do Pici, 60356-000, Fortaleza, CE, Brasil. E-mail: marcelo.sa@ufc.br.

*Autor para correspondência. 


\section{INTRODUCTION}

Brazilian fisheries production in 2009 was over 1 million ton which represented an increase of $7.3 \%$ in relation to 2008 . Out of that total, aquaculture had a share of $33.5 \%$ with a gross revenue over $\mathrm{R} \$ 1$ billion. Among the fish species cultivated in Brazil, the Nile tilapia, Oreochromis niloticus, is the top one with a total production of 132,957ton in 2009 (MPA, 2011). Brazil is one of the greatest world producers of farmed tilapia, after China, Egypt, Philippines, Indonesia, Thailand, and Taiwan in decreasing order (FAO, 2011). Among the Brazilian states, the Ceará is its greatest tilapia producer with a production of 32,812 ton or $24.7 \%$ of the country's total production in 2009 (MPA, 2011).

The production of tilapia in ponds and cages is considered a non-efficient process because just 5$15 \%$ of all nutrients delivered to fish as fertilizers or diets are converted in fish biomass. Therefore, the majority of nitrogen and phosphorus added to tilapia's ponds are lost to the environment and may cause its eutrophication and, as a consequence, the deterioration of lakes and rivers. One new alternative to maximize the use of nutrients in tilapia's ponds is the adoption of the substrate-based systems in which sub aquatic hard surfaces are installed for periphyton development (ASADUZZAMAN et al., 2009).

Periphyton is the general designation for the microorganisms that thrive in any submerged substrate and it is formed by algae, bacteria, fungi, aquatic invertebrates, protozoa and debris (POMPÊO \& MOSCHINI-CARLOS, 2003). Periphyton can be efficiently used as food by tilapia and others omnivorous fish, such as carps (DEMPSTER et al., 1993). Besides, the sub aquatic substrates placed in the rearing units are also colonized by nitrifying bacteria and can act as biological filters, reducing the levels of toxic ammonia in water (AZIM \& LITTLE, 2006). In Asia, several works have already been carried out to investigate the benefits of periphyton in aquaculture ponds (KESHAVANATH \& WAHAB, 2001). Although promising, the substrate-based systems still require careful assessing to prove their sustainability (AZIM et al., 2004b).

The present work was performed in laboratory conditions to answer the following questions about the substrate-based systems for Nile tilapia culture: (1) could the submerged substrates added in the rearing units bring any negative impact on water quality and fish growth performance? (2) Is it possible to reduce by half the daily feeding allowances to fish in the substrate-based units without any detriment in fish growth? Additionally, it was also aimed to validate a lab-scale model to study periphyton-based systems for fish culture. Once validated the experimental model will be useful as a research tool to develop suitable managements for substrate-based aquaculture systems.

\section{MATERIAL AND METHODS}

One thousand male sex reversed Nile tilapia, Oreochromis niloticus, fingelings were obtained at the Centro de Pesquisas em Aquicultura of the Departamento Nacional de Obras Contras as Secas (DNOCS) in Pentecoste, Ceará State, Brazil (3॰47'40.49''S; 39¹6'36.07''W). Initially, fish stayed in the reception tank for one week to acclimatize themselves to the laboratory conditions. Over the acclimatization period, fish fed a high-protein commercial diet (Nutripeixe AL55) in four daily meals at $0800,1100,1400$ and $1700 \mathrm{~h}$. The daily feeding rate was equal to $10 \%$ of the stocked biomass.

Twenty 25L polyethylene outdoor aquaria were used in the present work to hold experimental fish. The aquaria had a cotton mesh cover to prevent fish escape. At the onset of the experiment, three fingerlings $(0.77 \pm 0.09 \mathrm{~g})$ were stocked in each $25 \mathrm{~L}$ polyethylene aquarium (12 fish $\mathrm{m}^{-2}$ ). No artificial aeration was provided to the aquaria and the system was stagnant, that is, new water was supplied to aquaria just to replenish the water lost by evaporation Fish were maintained in the experimental system for 6 weeks.

In the present work, two experimental factors were evaluated simultaneously in a completely randomized design arranged in a $2 \times 2$ factorial mode. There were two different feeding regimes and the presence or the absence of periphyton in aquaria $(n=5)$. The fish fed on the artificial diet according to the feeding regime designed by "Full" received daily feeding rates ranging from $25 \%$ to $10 \%$ depending on the fish biomass. In the "Half-fed" feeding regime, the daily feeding rates adopted to feed fish were divided by two. Seven small plastic bottles were totally submerged in the aquarium's water to allow the periphyton development. The total surface area of the bottles was $1260 \mathrm{~cm}^{2}$ which represented $52 \%$ of the aquarium's surface area. Fifteen days before fish stocking in the aquaria, the plastic bottles were put into each aquaria intended to develop periphyton. In the same day of bottle placement, a $250 \mathrm{~mL}$ inoculation of phytoplankton rich water was carried out in all aquaria. All stocked fish were fed with the same artificial diet used during the acclimatization period. The amount of feed allowed to each aquarium was adjusted fortnightly after fish body weightings. 
Water quality, fish performance and periphyton growth variables were observed in the present work. The water temperature, $\mathrm{pH}$, gross primary productivity and the concentrations of total ammonia, nitrite and reactive phosphorus were monitored weekly in all aquaria. The analytical determinations of total ammonia, nitrite and reactive phosphorus were carried out according to the guidelines presented by APHA (1999). The gross primary productivity of water was measured following the light and dark bottles methodology (BOYD, 1979).

One extra bottle was set into the designed aquaria in the beginning of the trial to determine the periphyton productivity. After fifteen days, these extra bottles were removed from the designed aquaria and their periphyton films scraped carefully with a blade. The wet periphyton biomasses were put overnight on Petri plates inside an electric oven at $105^{\circ} \mathrm{C}$. The dry periphyton biomass was weighted in a semi-analytical scale. At the end of the experiment, the same procedure was carried out with all periphyton bottles. Fish final body weight, survival, specific growth rate (ln final body weight $-\ln$ initial body weight $/ \mathrm{n}^{\mathrm{o}}$ of day x 100 ), yield and feed conversion rate (feed allowance/fish weight gain) were observed in all repetitions.

The water quality and growth performance results were submit to the two-way ANOVA. When the differences were significant, the means were compared two-by-two using the test of Tukey. The periphyton productivities at the start and end of the experiment were compared by the one-way ANOVA. The statistical analyses were performed with the aid of the SigmaStat 2.0 software (JANDEL STATISTIC, 1995). The level of significance of 5\% was adopted in all statistical analyses.

\section{RESULTS AND DISCUSSION}

Visible green biofilms were formed on the bottles' surfaces just after two weeks the incubation of bottles in water. On average, $4.3 \mathrm{mg}$ of dry periphyton biomass were weighted per $\mathrm{cm}^{2}$ (Table 1). That value is comparable to the better results observed by AZIM et al. (2002a) using different substrates (bamboo, jutestick and kanchi) and higher to the initial periphyton density reported by HUCHETTE \& BEVERIDGE (2003) who added plastic bottles to tilapia cages. Therefore, a good periphyton development was achieved in the present work.

Significantly lower densities of periphyton biomass were observed in the bottles at the end of the present experiment when compared to the initial values. This result demonstrates that periphyton was actively fed by tilapia juveniles in the aquaria and confirms the findings of DEMPSTER et al. (1993) who said that periphyton is eagerly consumed be tilapia. The average final periphyton density in the half-fed aquaria was significantly lower than in the full-fed aquaria (Table 1). Therefore, tilapia fed on more periphyton when the daily allowance of artificial feed to aquaria was lower and suggests that the artificial diet was more preferred by tilapia than periphyton. The activity of grazing periphyton probably spends more energy than the activity of feeding a finely ground artificial diet. Hence, tilapia seems to have chosen the feeding activity that has spared more energy to it.

On average, the water temperature in aquaria from 08:00 to $16: 00$ was $29.1 \pm 2.89^{\circ} \mathrm{C}$; the water $\mathrm{pH}$ at 0800,1200 and $1600 \mathrm{~h}$ were $7.63 \pm 0.05 ; 8.20 \pm 0.10$ and $8.97 \pm 0.09$, respectively. The results of water temperature and $\mathrm{pH}$ are inside the proper ranges for tilapia growth (EL-SAYED, 2006). The reduction of 50\% in the daily feeding rates allowed to fish has significantly lowered the concentrations of ammonia, nitrite and phosphorus in the rearing water (Table 2). LIN and YI (2003) have also achieved in a Nile tilapia study significant reductions in nitrogenous (-64\%) and phosphorus $(-54 \%)$ wastes by optimizing the feeding regime employed. In that work, the feeding rates were reduced from $100 \%$ to $50 \%$ of the fish's satiation. The main input of nitrogen and phosphorus in intensive aquaculture systems is through the delivery of artificial diet to fish (DIANA, 2009). This is a desirable feature in aquaculture units because it means fewer problems with heavy phytoplankton blooms which use the high levels of nutrients in water to grow. Intense phytoplankton can bring problems with low concentration of dissolved oxygen in water (CARSTENSEN et al., 2007).

Table 1 - Periphyton density $\left(\mathrm{mg} \mathrm{cm} \mathrm{cm}^{-2}\right.$; dry matter) in $180 \mathrm{~cm}^{2}$ plastic bottles submerged in 25L polyethylene outdoor aquaria stocked with $0.77 \mathrm{~g}$ Nile tilapia, Oreochromis niloticus, juveniles for 6 weeks. Fish were submitted to two different feeding regimes (mean \pm s.d.; $\mathrm{n}=5$; three fish/aquarium)

\begin{tabular}{llll}
\hline & \multicolumn{2}{c}{ Feeding rate ${ }^{1}$} & \multicolumn{2}{c}{ End } & ANOVA P \\
& \multicolumn{1}{c}{ Start } & \multicolumn{1}{c}{ End } & \\
\hline Full & $4.43 \pm 0.70$ & $1.04 \pm 0.15$ & $<0.05$ \\
Half & $4.28 \pm 0.56$ & $0.47 \pm 0.10$ & $<0.05$ \\
ANOVA P & $\mathrm{ns}^{2}$ & $<0.05$ & \\
\hline
\end{tabular}

${ }^{1}$ Full: the feeding rates advised by the laboratory's table were followed completely; Half: the feeding rates in the laboratory's table were divided by two (see text for details);

${ }^{2}$ Not significant $(\mathrm{P}>0.05)$. 
Table 2 - Water quality indicators of $25 \mathrm{~L}$ polyethylene outdoor aquaria provided with or without $180 \mathrm{~cm}^{2}$ plastic bottles for periphyton development which were stocked with Nile tilapia, Oreochromis niloticus, juveniles (initial body weight $=0.77 \pm 0.09 \mathrm{~g}$ and initial body length $=2.8 \pm 0.20 \mathrm{~cm}$ ) for 6 weeks. Fish were submitted to two different feeding regimes (mean \pm s.d.; $\mathrm{n}=5$; three fish/aquarium)

\begin{tabular}{|c|c|c|c|c|}
\hline \multirow{2}{*}{ Variable $^{1}$} & \multirow{2}{*}{ Feeding rate ${ }^{2}$} & \multicolumn{3}{|c|}{--Periphyton ${ }^{3}-$} \\
\hline & & no & & yes \\
\hline \multirow{2}{*}{ Gross primary productivity ${ }^{4}\left(\mathrm{mg} \mathrm{L}^{-1} \mathrm{~h}^{-1}\right)$} & Full & $0.27 \pm 0.08 \mathrm{a}^{5}$ & & $0.20 \pm 0.05 \mathrm{~b}$ \\
\hline & Half & $0.24 \pm 0.05 \mathrm{a}$ & & $0.18 \pm 0.03 \mathrm{~b}$ \\
\hline \multirow{2}{*}{ Total ammonia $\left(\mathrm{mg} \mathrm{L}^{-1}\right)$} & Full & $0.60 \pm 0.09 \mathrm{~A}$ & & $0.57 \pm 0.05 \mathrm{~A}$ \\
\hline & Half & $0.28 \pm 0.04 \mathrm{~B}$ & & $0.29 \pm 0.01 \mathrm{~B}$ \\
\hline \multirow{2}{*}{ Nitrite $\left(\mathrm{mg} \mathrm{L}^{-1}\right)$} & Full & $0.77 \pm 0.67 \mathrm{~A}$ & & $0.75 \pm 0.41 \mathrm{~A}$ \\
\hline & Half & $0.33 \pm 0.05 \mathrm{~B}$ & & $0.37 \pm 0.14 \mathrm{~B}$ \\
\hline \multirow{2}{*}{ Reactive phosphorus $\left(\mathrm{mg} \mathrm{L}^{-1}\right)$} & Full & $0.70 \pm 0.12 \mathrm{~A}$ & & $0.67 \pm 0.28 \mathrm{~A}$ \\
\hline & Half & $0.42 \pm 0.19 \mathrm{~B}$ & & $0.43 \pm 0.24 \mathrm{~B}$ \\
\hline Factor & $\begin{array}{l}\text { GPPo-way } \\
\text { GP }\end{array}$ & $\mathrm{NH}_{3}-\mathrm{NH}_{4}^{+}$ & $\mathrm{NO}_{2}^{-}$ & $\mathrm{PO}_{4}^{-3}$ \\
\hline Feeding rate & $\mathrm{ns}^{6}$ & $<0.05$ & $<0.05$ & $<0.05$ \\
\hline Periphyton & $<0.05$ & ns & ns & ns \\
\hline Feed $\mathrm{x}$ periphyton & ns & ns & ns & ns \\
\hline
\end{tabular}

${ }^{1}$ The results refer to the last experimental week;

${ }^{2}$ Full: the feeding rates advised by the laboratory's table were followed completely; Half: the feeding rates in the laboratory's table were divided by two (see text for details);

${ }^{3}$ Seven small plastic bottles (total surface area $=1260 \mathrm{~cm}^{2}$ or $52 \%$ of the aquarium's surface area) were put into each aquaria intended to develop periphyton;

${ }^{4}$ Gross primary productivity was calculated by the light and dark bottle method after $3 \mathrm{~h}$ of water incubation (BOYD, 1979);

${ }^{5}$ For a same variable, means not sharing a same lower case or capital letter in a row and column, respectively, are significantly different between themselves by the Tukey's test $(\mathrm{P}<0.05)$; means without any letter are not significantly different between themselves;

${ }^{6}$ Not significant $(\mathrm{P}>0.05)$.

In the present work, the placement of underwater bottles in aquaria for periphyton development has caused a reduction in the abundance of phytoplankton as detected by the gross primary productivity results (Table 2). The same was observed by AZIM et al. (2004a), AZIM \& LITTLE (2006) and ASADUZZMAN et al. (2009) who have suggested that the competition between phytoplankton and periphyton for nutrients can lower the phytoplankton abundance when a good periphyton development occurs. Additionally, AZIM et al. (2003) have pointed out that there is an inverse relationship between periphyton growth and water transparency. The authors observed that periphyton was a source of turbidity because there was a dislodgement of periphytic material to the water. Hence, higher water turbidity means less light for phytoplankton photosynthesis. This phenomenon should not be seen as a problem to fish nurture because tilapia juveniles use periphyton better than phytoplankton as food (DEMPSTER et al., 1993).

Conversely, in the present work it was not observed the role of periphyton as a biological filter which disagrees with the findings of AZIM et al. (2004a) and ASADUZZMAN et al. (2009). The concentrations of total ammonia and nitrite in the water were not reduced by periphyton (Table 2). The efficiency of periphyton as a biological filter increases with the increase of the area for periphyton colonization (AZIM et al., 2004a). These authors have found the best results in biological filtration when the substrates with periphyton had a superficial area equal to $100 \%$ of the pond surface. In the present work, the superficial area in the bottles for periphyton development was only $50 \%$ of the aquarium surface. Therefore, we speculate that if that area was higher, nearly $100 \%$ of the aquarium surface, significant effects of periphyton on ammonia and nitrite could have been seen in the present work.

The periphyton-based aquaria stocked with half-fed fish exhibited final body weight, specific growth rate (SGR) and yield significantly better than those observed in the respective non-periphyton aquaria (Table 3). AZIM et al. (2002b) and AZIM et al. (2004b) have observed the same in studies with Indian carps stocked in commercial ponds. On the other hand, the same was not observed in aquaria where fish received full feeding rates in the present work. Therefore, in lack of sufficient exogenous feed (ration), fish fed actively more on endogenous feed (periphyton) 
Table 3 - Growth performance of Nile tilapia, Oreochromis niloticus, juveniles (initial body weight $=0.77 \pm 0.09 \mathrm{~g}$ and initial body length $=$ $2.8 \pm 0.20 \mathrm{~cm}$ ) reared for 6 weeks in $25 \mathrm{~L}$ polyethylene outdoor aquaria provided with or without $180 \mathrm{~cm}^{2}$ plastic bottles for periphyton development and submitted to two different feeding rates (mean \pm s.d.; $n=5$; three fish/aquarium)

\begin{tabular}{|c|c|c|c|c|c|}
\hline Variable & Feeding rate ${ }^{1}$ & \multicolumn{2}{|c|}{ no } & \multicolumn{2}{|c|}{ yes } \\
\hline \multirow{2}{*}{ Final body weight (g) } & Full & \multicolumn{2}{|c|}{$7.22 \pm 1.06 \mathrm{aA}^{3}$} & \multicolumn{2}{|c|}{$7.58 \pm 0.43 \mathrm{aA}$} \\
\hline & Half & \multicolumn{2}{|c|}{$4.65 \pm 0.36 \mathrm{aB}$} & \multicolumn{2}{|c|}{$6.22 \pm 0.64 \mathrm{bB}$} \\
\hline \multirow{2}{*}{ Survival (\%) } & Full & \multicolumn{2}{|c|}{$80.0 \pm 18.2 \mathrm{~A}$} & \multicolumn{2}{|c|}{$83.4 \pm 16.7 \mathrm{~A}$} \\
\hline & Half & \multicolumn{2}{|c|}{$93.3 \pm 14.9 \mathrm{~B}$} & \multicolumn{2}{|c|}{$100.0 \pm 0.0 \mathrm{~B}$} \\
\hline \multirow{2}{*}{$\mathrm{SGR}^{4}\left(\% \mathrm{BW}\right.$ day $\left.^{-1}\right)$} & Full & \multicolumn{2}{|c|}{$5.61 \pm 0.29 \mathrm{aA}$} & \multicolumn{2}{|c|}{$5.29 \pm 0.28 \mathrm{aA}$} \\
\hline & Half & \multicolumn{2}{|c|}{$4.27 \pm 0.27 \mathrm{aB}$} & \multicolumn{2}{|c|}{$4.72 \pm 0.21 \mathrm{bB}$} \\
\hline \multirow{2}{*}{ Yield $\left(\mathrm{g} \mathrm{m}^{-2}\right)$} & Full & \multicolumn{2}{|c|}{$88.5 \pm 20.0 \mathrm{aA}$} & \multicolumn{2}{|c|}{$79.5 \pm 18.7 \mathrm{aA}$} \\
\hline & Half & \multicolumn{2}{|c|}{$54.2 \pm 9.1 \mathrm{aB}$} & \multicolumn{2}{|c|}{$72.2 \pm 14.8 \mathrm{bA}$} \\
\hline \multirow{2}{*}{$\mathrm{FCR}^{5}$} & Full & \multicolumn{2}{|c|}{$1.84 \pm 0.32 \mathrm{~A}$} & \multicolumn{2}{|c|}{$1.96 \pm 0.16 \mathrm{~A}$} \\
\hline & Half & \multicolumn{2}{|c|}{$1.41 \pm 0.27 \mathrm{~A}$} & \multicolumn{2}{|c|}{$1.13 \pm 0.12 \mathrm{~B}$} \\
\hline Factor & Weight & Survival & SGR & Yield & FCR \\
\hline Feeding rate & $<0.05$ & $<0.05$ & $<0.05$ & $<0.05$ & $<0.05$ \\
\hline Periphyton & $<0.05$ & $\mathrm{~ns}^{6}$ & $<0.05$ & $\mathrm{~ns}$ & $\mathrm{~ns}$ \\
\hline Feed $\mathrm{x}$ periphyton & $<0.05$ & $\mathrm{~ns}$ & $<0.05$ & $<0.05$ & $<0.05$ \\
\hline
\end{tabular}

${ }^{1}$ Full: the feeding rates advised by the laboratory's table were followed completely; Half: the feeding rates in the laboratory's table were divided by two (see text for details);

${ }^{2}$ Seven small plastic bottles (total surface area $=1260 \mathrm{~cm}^{2}$ or $52 \%$ of the aquarium's surface area) were put into each aquaria intended to develop periphyton;

${ }^{3}$ For a same variable, means not sharing a same lower case or capital letter in a row and column, respectively, are significantly different between themselves by the Tukey's test $(\mathrm{P}<0.05)$;

${ }^{4}$ Specific growth rate (SGR, \% body weight per day) $=\left[(\ln\right.$ final body weight $-\ln$ initial body weight $) / n^{\circ}$ of days $] \times 100 ;$

${ }^{5}$ Feed conversion ratio $=$ feed allowance $(\mathrm{g}) /$ fish weight gain $(\mathrm{g})$;

${ }^{6}$ Not significant $(\mathrm{P}>0.05)$.

to maintain its normal development. The feeding restriction imposed by the "half" regime, however, was severe because the fish's final body weight and growth for half-fed fish were significantly lower than those observed for full-fed fish, even in the substrate-based aquaria.

Fish survival was significantly higher in halffed aquaria than in full-fed aquaria. That was true both for aquaria with or without periphyton bottles (Table 3). The significantly lower concentrations of ammonia and nitrite in water (Table 2), which are toxic metabolites for aquatic animals, could explain the better results of survival in the former aquaria. The same was observed by AZIM et al. (2002b) in a study with Indian carps. The reduction in the feeding allowances to fish by $50 \%$ produced better FCR's results only in aquaria with periphyton bottles (Table 3). That demonstrates that the feeding restriction in periphyton-based aquaria has not hampered fish growth in the same degree as in the non-periphyton based aquaria. In the last case, fish growth was more severely affected because the animas did not have any other nutritional source beyond the balance diet. ASADUZZMAN et al. (2009) have found that the placement of bamboos in polyculture shrimp-fish ponds (M. rosenbergii and $\boldsymbol{O}$. niloticus) improved results of FCR. The same was not seen in the present work.

\section{CONCLUSION}

Submerged substrates placed in Nile tilapia rearing units do not bring any negative impact on water quality and fish growth performance. It was not possible to reduce by half the daily feeding allowances to fish in the substrate-based units without detriment in fish growth performance.

The lab-scale model used in the present work is valid to perform studies on periphyton-based systems for fish culture, especially if the sub aquatic area for periphyton development is close to $100 \%$ of the aquarium surface area.

\section{ACKNOWLEDGEMENTS}

The authors would like to express their gratitude to Centro de Pesquisa em Aquicultura, Departamento Nacional de Obras Contra as Secas, Pentecoste, Ceará, for the Nile tilapia fingerlings and to Purina do Brasil for the artificial diet. 


\section{REFERENCES}

APHA-American Public Health Association. Standard methods for the examination of water and waste water. 20.ed. Washington, D.C: APHA, 1999. 1325p.

ASADUZZAMAN, M. et al. Effects of addition of tilapia Oreochromis niloticus and substrates for periphyton developments on pond ecology and production in $\mathrm{C} / \mathrm{N}-$ controlled freshwater prawn Macrobrachium rosenbergii farming systems. Aquaculture, v.287, p.371-380, 2009. Available from: 〈http://www.sciencedirect.com>. Accessed: jan. 28, 2011. doi:10.1016/j.aquaculture.2008.11.011.

AZIM, M.E. et al. A comparison of fertilization, feeding and three periphyton substrates for increasing fish production in freshwater pond aquaculture in Bangladesh. Aquaculture, v.212, p.227-243, 2002a. Available from: <http:// www.sciencedirect.com>. Accessed: jan 28, 2011. doi:10.1016/ S0044-8486(02)00093-5.

AZIM, M.E. et al. Evaluation of polyculture of Indian major carps in periphyton-based ponds. Aquaculture, v.213, p.131149, 2002b. Available from: 〈http://www.sciencedirect.com>. Accessed: jan. 28, 2011. doi:10.1016/S0044-8486(02)00029-7.

AZIM, M.E. et al. Periphyton-water quality relationships in fertilized fishponds with artificial substrates. Aquaculture, v.228, p.169-187, 2003. Available from: <http:// www.sciencedirect.com>. Accessed: jan. 28, 2011. doi:10.1016/ S0044-8486(03)00319-3.

AZIM, M.E. et al. The effect of periphyton substrate density on production in freshwater polyculture ponds. Aquaculture, v.232, p.441-453, 2004a. Available from: <http:// www.sciencedirect.com>. Accessed: jan. 28, 2011. doi: $10.1016 / \mathrm{j}$.aquaculture.2003.08.010.

AZIM, M.E. et al. Periphyton-based pond polyculture system: a bioeconomic comparison of on-farm and on-station trials. Aquaculture, v.242, p.381-396, 2004b. Available from: <http://www.sciencedirect.com>. Accessed: jan. 28, 2011. doi: 10.1016/j.aquaculture.2004.09.008.

AZIM, M.E.; LITTLE D.E. Intensifying aquaculture production through new approaches to manipulating natural food. CAB Reviews: Perspectives in Agriculture, Veterinary Science, Nutrition and Natural Resources, v.1, p.1- 23, 2006.

BOYD, C.E. Water quality in warmwater fish ponds. Auburn: Auburn University, 1979. 359p.

CARSTENSEN, J.et al. Summer algal blooms in shallow estuaries: definition, mechanisms, and link to eutrophication. Limnology and Oceanography, v.52, n.1, p.370-384, 2007. Available from: 〈http://www.jstor.org/pss/40006087>. Accessed: sep. 02, 2011. doi: $10.4319 / 10.2007 .52 .1 .0370$.

DEMPSTER P.W. et al. Herbivory in the tilapia Oreochromis niloticus: a comparison of feeding rates on phytoplankton and periphyton. Journal of Fish Biology, v.43, p.385-392, 1993. Available from: <http://onlinelibrary.wiley.com.ez11.periodicos.capes.gov.br>. Accessed: sep 02, 2011. doi:10.1111/j.1095-8649.1993.tb00573.x.

DIANA, J.S. Aquaculture production and biodiversity conservation. BioScience, v.59, n.1, p.27-38, 2009. Available from: <http:// www.sciencedirect.com>. Accessed: jan 28, 2011. doi: 10.1525/ bio.2009.59.1.7.

EL-SAYED, A-F.M. Tilapia culture. Oxfordshire: CABI Publishing, 2006. 304p.

FAO - Food and Agriculture Organization of the United Nations. The state of world fisheries and aquaculture. Disponível em <http://www.fao.org>. Acesso em: 21 jul. 2011.

HUCHETTE, S.M.H.; BEVERIDGE, M.C.M. Technical and economical evaluation of periphyton-based cage culture of tilapia (Oreochromis niloticus) in tropical freshwater cages. Aquaculture, v.218, p.219-234, 2003. Available from: <http:/ /www.sciencedirect.com. Accessed: jan 28,. 2011. doi:10.1016/ S0044-8486(02)00414-3.

KEShaVAnATH, P.; WAHAB, M.A. Periphyton-based aquaculture and its potential in rural development, 2001. Dhaka, Bangladesh: Ahsania Mission, 2001. (Summary of an EC-INCO-DC Funded Workshop).

LIN, C.K.; YI, Y. Minimizing environmental impacts of freshwater aquaculture and reuse of pond effluents and mud. Aquaculture, v.226, p.57-68, 2003. Available from: <http:/ /www.sciencedirect.com>. Acessed: jan 28, 2011. doi:10.1016/ S0044-8486(03)00467-8

MPA - Ministério da Pesca e Aquicultura. Produção pesqueira e aquícola. Estatística 2008 - 2009. Available from: <http:/ /www.mpa.gov.br/mpa/seap/Jonathan/mpa3/dados/2010/Docs/ Caderno\%20Consolida\%C3\%A7\%C3\%A3o\%20dos\%20dados\%20 estatiscos \% 20 final $\% 20$ curvas $\% 20-\% 20$ completo.pdf $>$. Accessed: jul 21, 2011.

POMPÊO, M.L.M.; MOSCHINI-CARLOS, V. Perifíton: estrutura, dinâmica e métodos de estudos. In: Macrófitas aquáticas e perifíton - Aspectos ecológicos e metodológicos. São Carlos: RiMa, 2003. p.63-85. 